\title{
Changes in body composition and energy expenditure after six weeks' growth hormone treatment
}

\author{
J W Gregory, S A Greene, R T Jung, C M Scrimgeour, M J Rennie
}

\begin{abstract}
Changes in body composition and energy expenditure were assessed in 15 children after six weeks of human growth hormone (hGH) treatment. Body composition measurements were made by stable isotope labelled water $\left(\mathrm{H}_{2}{ }^{18} \mathrm{O}\right)$ dilution, bioelectrical impedance, and skinfold thickness techniques. Energy expenditure was assessed both by indirect ventilated hood calorimetry (resting energy expenditure) and the stable isotope doubly labelled water $\left({ }^{2} \mathbf{H}_{2}{ }^{18} \mathbf{O}\right)$ technique (free living daily total energy expenditure). Mean increases in weight of $0.96 \mathrm{~kg}$ and fat free mass of $1.37 \mathrm{~kg}$ and a mean decrease in fat mass of $0.41 \mathrm{~kg}$ were observed. Significant increases both in resting energy expenditure and free living daily energy expenditure were detected. Absolute changes in fat mass and resting energy expenditure were correlated. The data suggest (i) that the increase in the fat free mass is the most significant early clinical measure of hGH response and (ii) that hGH increases the metabolic activity of the fat free mass. Monitoring such changes may be predictive of the efficacy of hGH in promoting growth.
\end{abstract}

Although growth hormone has been available for the treatment of children with short stature for approximately 30 years, ${ }^{1}$ information on the association of the early metabolic effects of treatment to possible subsequent changes in body composition is limited. Metabolic studies (mostly made in the first one to two weeks of treatment) have shown that human growth hormone (hGH) is anabolic, indicated by nitrogen retention increasing within 24 hours $^{2-6}$ and reaching a maximum less than 14 days after initiation of treatment. ${ }^{7}$ Also the triceps skinfold thickness, which is a measure of fat mass, decreases six to 10 weeks after the start of treatment. However, studies of other indices of body composition have been made only after longer periods of treatment (for example, total body potassium estimated by ${ }^{40} \mathrm{~K}$ counting after seven months), ${ }^{8}$ and little attempt has been made to compare the extent of the possible effects, early and late.

There is very little information, none recent, on the energy expenditure changes associated with treatment and the available information is inconsistent. ${ }^{39}$ Most measurements of this sort were of resting energy expenditure and we are unaware of any attempts to measure free living daily total energy expenditure. Total energy expenditure may be affected by changes in well being which influence overall activity patterns. Furthermore, no attempts have been made to relate changes in total or resting energy expenditure to those in body composition in children treated with hGH. Accurate measurement of total energy expenditure in children was previously impossible in the free living state until the advent of the non-invasive doubly labelled water $\left({ }^{2} \mathrm{H}_{2}{ }^{18} \mathrm{O}\right)$ method using stable, nonradioactive isotopes. ${ }^{1011} \mathrm{We}$ hypothesised that the early metabolic effects of hGH treatment would result in increased energy expenditure, which may be predictive of the subsequent anthropometric effect of treatment. We have therefore measured, before and after six weeks hGH treatment, changes in body composition using $\mathrm{H}_{2}{ }^{18} \mathrm{O}$ dilution and compared the results with values obtained from two techniques more easily applicable routinely in the clinic, namely measurement of bioelectrical impedance and skinfold thickness. We have measured resting energy expenditure using indirect ventilated hood calorimetry and free living total energy expenditure using the ${ }^{2} \mathrm{H}_{2}{ }^{18} \mathrm{O}$ method to determine the effects of hGH treatment on energy expenditure and to see if such changes are related to changes in body composition. The results presented here are initial measurements from an ongoing study to assess the long term metabolic and energy expenditure effects of hGH and to discover whether early changes may be predictive of any long term growth promoting effects.

Patients and methods

Ethical approval for the study was obtained from the committee on medical ethics of Tayside Health Board. Fifteen patients (nine boys and six girls, table 1) participated, all of whom were recruited from the children's endocrine clinic and were to undergo a one year course of hGH treatment prescribed on clinical grounds. Nine patients had growth hormone insufficiency (concentration $<10 \mu \mathrm{g} / \mathrm{l}(<20 \mathrm{mU} /$ l) in response to a standard insulin stress test ${ }^{12}$ and six had growth hormone concentrations $\geqslant 10 \mu \mathrm{g} / \mathrm{l}(\geqslant 20 \mathrm{mU} / \mathrm{l})$ of whom four had normal variant short stature. The decision to treat case 3 (table 1) was based on a height velocity on the 10th centile for an 18 month period before entering the study. Before treatment with hGH, patients were admitted to the paediatric unit for a morning, having previously fasted from midnight. Height was measured using a Harpenden stadiometer and weight by a beam balance. Skinfold measurements (Holtain skinfold caliper) were made at the triceps, biceps, sub- 
Table 1 Pretreatment patient details

\begin{tabular}{|c|c|c|c|c|c|c|c|}
\hline $\begin{array}{l}\text { Case } \\
\text { No }\end{array}$ & Sex & $\begin{array}{l}\text { Growth } \\
\text { hormone } \\
\text { concentration } \\
(\mu g / l)^{*}\end{array}$ & $\begin{array}{l}\text { Age } \\
\text { (years) }\end{array}$ & $\begin{array}{l}\text { Height } \\
S D \\
\text { scoref }\end{array}$ & $\begin{array}{l}\text { Height } \\
\text { velocity } \\
\text { (cm/year) })\end{array}$ & $\begin{array}{l}\text { Weight } \\
(\mathrm{kg})\end{array}$ & Diagnosis \\
\hline $\begin{array}{r}1 \\
2 \\
3 \\
4 \\
5 \\
6 \\
7 \\
8 \\
9 \\
10 \\
11 \\
12 \\
13 \\
14 \\
15\end{array}$ & $\begin{array}{l}\mathbf{M} \\
\mathbf{M} \\
\mathbf{M} \\
\mathbf{F} \\
\mathbf{M} \\
\mathbf{M} \\
\mathbf{F} \\
\mathbf{F} \\
\mathbf{F} \\
\mathbf{F} \\
\mathbf{M} \\
\mathbf{F} \\
\mathbf{M} \\
\mathbf{M} \\
\mathbf{M}\end{array}$ & $\begin{array}{r}0 \cdot 8 \\
2 \cdot 1 \\
4 \cdot 3 \\
4 \cdot 6 \\
5 \cdot 4 \\
5 \cdot 9 \\
6 \cdot 8 \\
7 \cdot 0 \\
8 \cdot 9 \\
11 \cdot 8 \\
11 \cdot 9 \\
23 \cdot 5 \\
24 \cdot 4 \\
34 \cdot 0 \\
36 \cdot 2\end{array}$ & $\begin{array}{r}9 \cdot 46 \\
11 \cdot 56 \\
7 \cdot 62 \\
8 \cdot 17 \\
13.71 \\
7 \cdot 84 \\
11.85 \\
7.65 \\
10 \cdot 29 \\
11 \cdot 01 \\
12 \cdot 61 \\
7 \cdot 39 \\
9 \cdot 44 \\
14 \cdot 26 \\
9.79\end{array}$ & $\begin{array}{r}-1.03 \\
1.06 \\
-3.12 \\
-2.09 \\
-0.92 \\
-2.43 \\
-4.60 \\
-1.87 \\
-1.86 \\
-2.60 \\
-2.79 \\
-2.15 \\
-3.20 \\
-3.81 \\
-3.17\end{array}$ & $\begin{array}{l}3 \cdot 73 \\
4.82 \\
8 \cdot 24 \\
3.43 \\
8.27 \\
5.59 \\
3.33 \\
5 \cdot 15 \\
4.00 \\
3.75 \\
6.31 \\
4.68 \\
3.08 \\
4.63 \\
3.96\end{array}$ & $\begin{array}{l}27 \cdot 40 \\
43 \cdot 30 \\
15 \cdot 65 \\
19 \cdot 00 \\
38 \cdot 30 \\
19 \cdot 30 \\
23 \cdot 40 \\
18 \cdot 50 \\
33 \cdot 13 \\
26 \cdot 90 \\
26 \cdot 60 \\
18 \cdot 15 \\
22 \cdot 10 \\
32 \cdot 60 \\
20 \cdot 70\end{array}$ & $\begin{array}{l}\text { Panhypopituitary } \\
\text { Craniopharyngioma } \\
\text { IGHD } \\
\text { Turner's syndrome } \\
\text { After acute lymphoblastic leukaemia } \\
\text { IGHD } \\
\text { IGHD } \\
\text { Turner's syndrome } \\
\text { Turner's syndrome } \\
\text { NVSS } \\
\text { After acute lymphoblastic leukaemia } \\
\text { Turner's syndrome } \\
\text { NVSS } \\
\text { NVSS } \\
\text { NVSS }\end{array}$ \\
\hline $\begin{array}{l}\text { Mean } \\
\text { SE }\end{array}$ & & $\begin{array}{r}12 \cdot 7 \\
3.0\end{array}$ & $\begin{array}{r}10.18 \\
0.59\end{array}$ & $\begin{array}{r}-2.31 \\
0.35\end{array}$ & $\begin{array}{l}4 \cdot 86 \\
0 \cdot 42\end{array}$ & $\begin{array}{r}25 \cdot 66 \\
2 \cdot 09\end{array}$ & \\
\hline
\end{tabular}

${ }^{*}$ Growth hormone response before hGH treatment; $1 \mu \mathrm{g} / \mathrm{l}=2 \mathrm{mU} / \mathrm{l}$.

†Height expressed as SD score for chronological age.

Height velocity calculated over a six month period before treatment.

IGHD, isolated growth hormone deficiency; NVSS, normal variant short stature.

scapular, and suprailiac sites. ${ }^{13}$ Separate regression equations were used for converting the sum of the four skinfold thicknesses into body density for prepubertal ${ }^{14}$ and adolescent ${ }^{13}$ children. Percentage body fat was calculated ${ }^{15}$ and thence fat mass and fat free mass could be derived for each child. Total body water was estimated from $\mathrm{H}_{2}{ }^{18} \mathrm{O}$ dilution (measured in the basal and five hour post dose urine specimens) using the formula of Schoeller $e^{-a^{16}}$ and also by bioelectrical impedence which has been validated for use in children ${ }^{17}$ and specifically in those with growth disorders. ${ }^{18}$ Impedance measurements were made using a Holtain body composition analyser (Holtain Limited). The technique is simple to perform and highly acceptable to patients. Total body water (TBW) was calculated from the regression equation:

$$
\text { TBW }=0.79+0.55\left(\mathrm{Ht}^{2} / \text { Impedance }\right)^{18}
$$

Assuming fat free mass(FFM) is composed of $73 \%$ water by weight, ${ }^{19}$ then FFM $=\mathrm{TBW} / 0.73$ and

Fat mass $=$ total body weight - FFM.

The doubly labelled water method for estimation of total energy expenditure has now been used in several centres with good precision (2$8 \%$ ) in adults ${ }^{1120-21}$ and infants ${ }^{22}$ and is now being applied to children. ${ }^{23}$ It is based on the measurement of carbon dioxide production from the difference between the elimination rates of the deuterium $\left({ }^{2} \mathrm{H}_{2}\right)$ and ${ }^{18} \mathrm{O}$ with which the water is labelled. Because of the action of carbonic anhydrase, both water and bicarbonate pools are labelled with ${ }^{18} \mathrm{O}$ and the disappearance rate of ${ }^{18} \mathrm{O}$ is determined by the production of carbon dioxide and loss of water from the body. ${ }^{2} \mathrm{H}$ is lost only as water. The difference in the disappearance rates of ${ }^{18} \mathrm{O}$ and ${ }^{2} \mathrm{H}$ is proportional to the production of carbon dioxide and assuming a respiratory quotient (RQ) of $0.85,{ }^{24}$ total energy expenditure can be calculated using Weir's equation. ${ }^{25}$

At 0900 each patient took by mouth $0.3 \mathrm{~g}$ $\mathrm{H}_{2}{ }^{18} \mathrm{O} / \mathrm{kg}$ estimated total body water $\left({ }^{18} \mathrm{O}\right.$ was 10.4 atom \%, Isotec Inc) and $0.12 \mathrm{~g}^{2} \mathrm{H}_{2} \mathrm{O} / \mathrm{kg}$ estimated total body water $\left({ }^{2} \mathrm{H}\right.$ was $99 \cdot 8$ atom $\%$, Sigma Chemical Company). Urine speci- mens for analysis were taken before and three, four, and five hours after ingestion of the isotope. For two weeks thereafter, the second morning urine specimen was collected (usually just before leaving for school). Isotope ratio measurements for ${ }^{18} \mathrm{O}$ and ${ }^{2} \mathrm{H}$ were carried out using a Finnigan MAT Delta $\mathrm{D}$ gas isotope ratio mass spectrometer fitted with an automated breath gas analysis system. ${ }^{26}{ }^{18} \mathrm{O}$ enrichment was measured after equilibration of $400 \mu \mathrm{l}$ of urine with $5 \%$ carbon dioxide in $20 \mathrm{ml}$ Vacutainers (Becton Dickinson) using the automated inlet system. ${ }^{2} \mathrm{H}$ was measured as ${ }^{2} \mathrm{H}_{2}$ after reduction of $8 \mu \mathrm{l}$ urine samples with zinc at $450^{\circ} \mathrm{C}$. ${ }^{27}{ }^{2} \mathrm{H}_{2}$ samples were manually introduced into the mass spectrometer.

After isotopic enrichment of the urine was measured, a rate constant for the disappearance of each isotope was determined. The integration method of Coward et al was employed to calculate the carbon dioxide production rate. ${ }^{28}$

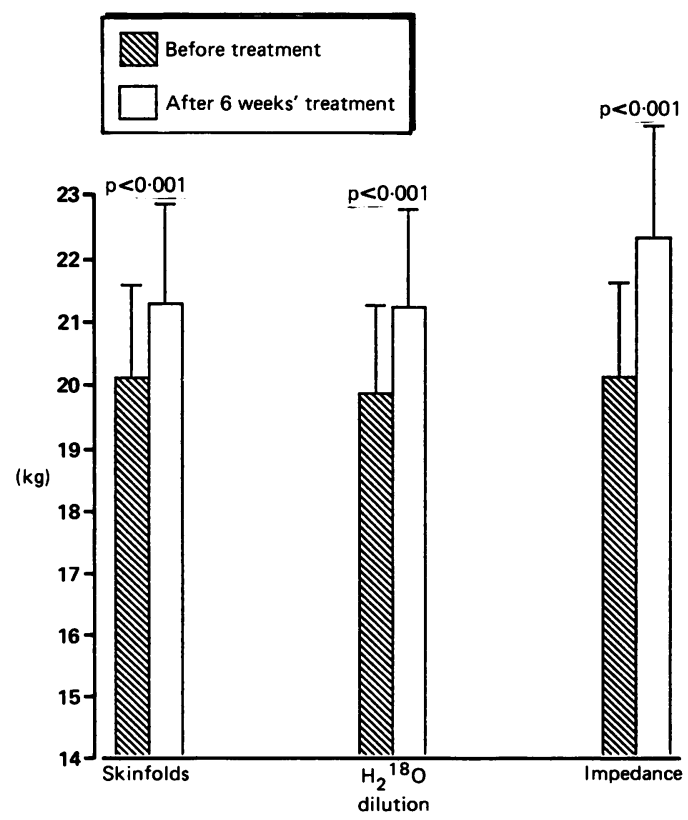

Figure 1 Mean (SE) changes in fat free mass by the three techniques. 


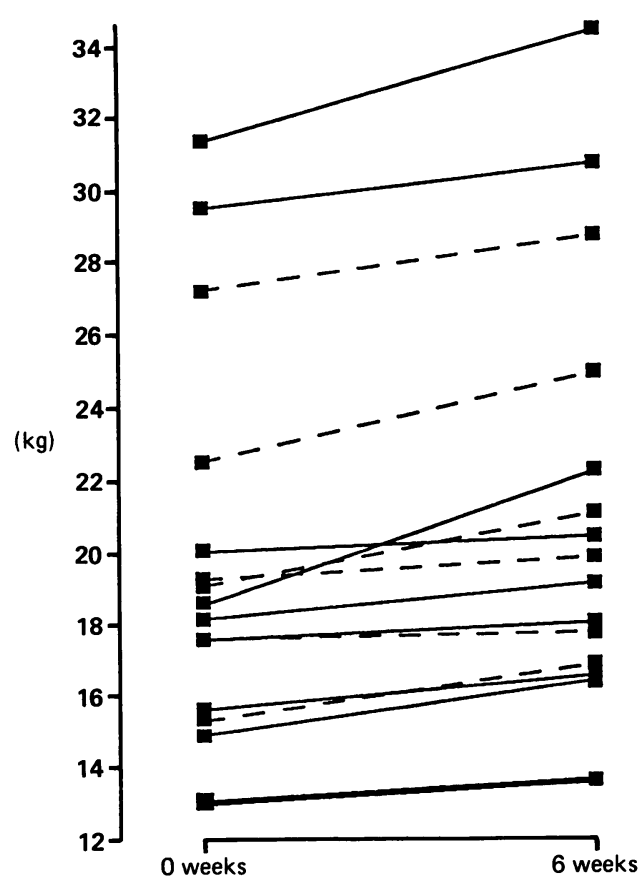

Figure 2 Individual changes in fat free mass by $\mathrm{H}_{2}{ }^{18} \mathrm{O}$ dilution. Growth hormone concentration before treatment: $\geqslant 10 \mu g / l(\geqslant 20 \mathrm{mU} / \mathrm{l})$, broken line; $<10 \mu \mathrm{g} / \mathrm{l}(<20 \mathrm{mU} / \mathrm{l})$, solid line.

Total energy expenditure calculated by this method is thus a mean value for energy expenditure over a two week period.

Resting energy expenditure was estimated in a fasting state and thermoneutral environment by an indirect ventilated hood calorimeter ${ }^{29}$ built by the medical physics department of Ninewells Hospital. Oxygen and carbon dioxide concentrations were measured by paramagnetic (Taylor, Servomex) and infrared (SS-200, Analytical Development Company Ltd) analyses respectively. Calorimeter operation and data

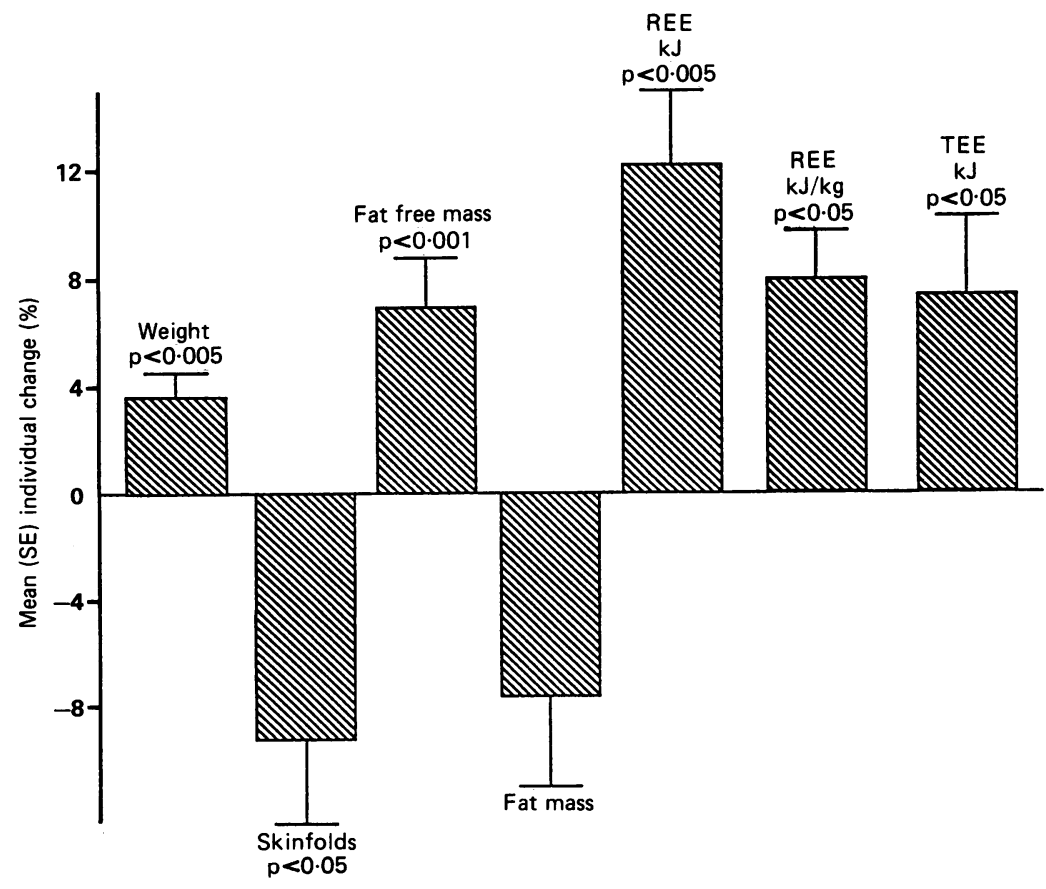

Figure 3 Effect of six weeks' treatment with hGH. REE, resting energy expenditure; $T E E$, total energy expenditure.
Table 2 Body composition before and after $h G H$ treatment. Results are mean $(S E)$

\begin{tabular}{llll}
\hline & 0 Weeks & 6 Weeks & $p$ Value \\
\hline Weight $(\mathrm{kg})$ & $25 \cdot 66(2 \cdot 09)$ & $26.62(2 \cdot 23)$ & $<0.005$ \\
Sum of 4 skinfolds (mm) & $36 \cdot 1(3.6)$ & $32.6(3.5)$ & $<0.05$ \\
Fat free mass (kg)* & $19 \cdot 83(1 \cdot 44)$ & $21 \cdot 20(1.57)$ & $<0.001$ \\
Fat mass $(\mathrm{kg})^{*}$ & $5.83(0.90)$ & $5.42(0.91)$ & $\mathrm{NS}$ \\
\hline
\end{tabular}

${ }^{*} \mathrm{By} \mathrm{H}_{2}{ }^{18} \mathrm{O}$ dilution.

processing were carried out using a Commodore 64 microcomputer; resting energy expenditure was calculated from Weir's equation. ${ }^{25}$

Patients were treated with subcutaneous injections of recombinant hGH (Norditropin, Novo Norkdisk) at a dose of $2 \mathrm{U}$ daily. This resulted in a mean (SE) dose of $15 \cdot 1(0 \cdot 8) \mathrm{U} / \mathrm{m}^{2} /$ week or $0.57(0.04) \mathrm{U} / \mathrm{kg} /$ week. Before and after treatment results were statistically analysed using a rank Wilcoxon test for paired data and the Spearman rank order correlation coefficient test. Significance was assigned at the level of $5 \%$.

\section{Results}

BODY COMPOSITION (figs 1 and 2, table 2)

Pretreatment values of fat free mass in individual patients by each of the three techniques were highly correlated $\left(\mathrm{H}_{2}{ }^{18} \mathrm{O}\right.$ dilution compared with skinfolds, $r=0.98, p<0.0005$ and $\mathrm{H}_{2}{ }^{18} \mathrm{O}$ dilution compared with impedance, $\mathrm{r}=$ $0.95, \mathrm{p}<0.0005$ ) and all three methods gave similar values of the changes of fat free mass (fig 1). Therefore only body composition information obtained from $\mathrm{H}_{2}{ }^{18} \mathrm{O}$ dilution is shown in

Table 3 Energy expenditure before and after $h G H$ treatment. Results are mean $(S E)$

\begin{tabular}{|c|c|c|c|}
\hline & OWeeks & 6 Weeks & p Value \\
\hline Respiratory quotient & $0.79(0.02)$ & $0.80(0.01)$ & NS \\
\hline $\begin{array}{l}\text { Resting energy expenditure } \\
\text { (kJ/day) }\end{array}$ & $4088(142)$ & $4568(158)$ & $<0.005$ \\
\hline $\begin{array}{l}\text { Resting energy expenditure } \\
\text { (kJ/kg fat free mass/day) }\end{array}$ & $211(10)$ & $222(11)$ & $<0.05$ \\
\hline $\begin{array}{l}\text { Total energy expenditure } \\
(\mathrm{kJ} / \mathrm{kg} / \text { day })\end{array}$ & $7171(577)$ & $7677(609)$ & $<0.05$ \\
\hline
\end{tabular}

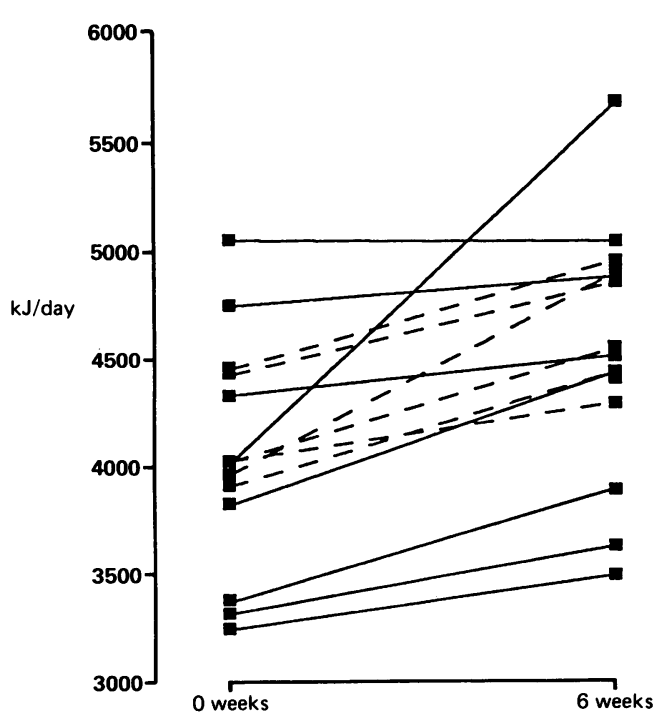

Figure 4 Individual changes in resting energy expenditure. Growth hormone concentration before treatment: $\geqslant 10 \mu \mathrm{g} / \mathrm{l}$ $(\geqslant 20 \mathrm{mU} / \mathrm{l})$, broken line; $<10 \mu \mathrm{g} / \mathrm{l}(<20 \mathrm{mU} / \mathrm{l})$, solid line. 
fig 2 and table 2. Twelve of the 15 patients gained weight over the six week period. All 15 patients increased their fat free mass (fig 2).

ENERGY EXPENDITURE (figs 3 and 4 , table 3 ) Because of the difficulty in persuading one 7 year old patient to lie still, reliable results of resting energy expenditure changes are available in only 14 of 15 patients. There was a significant mean increase of $12.1 \%(\mathrm{p}<0.005)$ in resting energy expenditure in individual subjects over six weeks with only one patient (case 5) demonstrating a decrease over that time (fig 4). However, when resting energy expenditure was expressed/ $\mathrm{kg}$ fat free mass, four patients (cases $2,4,5$, and 11) showed a mean decrease of $2 \cdot 8 \%$, though the overall mean individual increase in resting energy expenditure/kg fat free mass of $7 \cdot 9 \%$ was still significant $(p<0.05)$. Measurement of total energy expenditure also showed a significant mean individual increase of $7 \cdot 3 \%(\mathrm{p}<0.05)$ over six weeks, although in three patients (cases 3,5 , and 13) the values did decrease. The mean changes in response to treatment are summarised in table 3 and fig 3 .

Pretreatment resting and total energy expenditure correlated significantly with weight $(\mathrm{r}=0.78, \mathrm{p}<0.005$ and $\mathrm{r}=0.68, \mathrm{p}<0.05$ respectively) and with fat free mass $(r=0.87, p<0.005$ and $r=0.62, p<0.05$ respectively). Pretreatment resting and total energy expenditure were correlated $(r=0.54, p=0.05)$. After six weeks of treatment with hGH there was an inverse correlation between absolute changes in fat mass and resting energy expenditure $(r=-0.53, p=0.05)$. Absolute increases in resting and total energy expenditure over the six week period were positively correlated $(r=0.78, p<0.01)$. However, none of these observed changes in energy expenditure was correlated with the differing doses of hGH (expressed either as U/ $\mathrm{kg} /$ week or $\mathrm{U} / \mathrm{m}^{2} /$ week) received by these patients.

\section{Discussion}

After six weeks of hGH treatment we observed significant increases in fat free mass that have not, so far as we know, been previously detected in children after such a short period of treatment. Unlike the results obtained by previous work in adults, ${ }^{30}$ however, we have also observed a significant increase in weight, well above that anticipated over a six week period in a growing child. The study in adults has shown an early increase in fluid retention in response to hGH that might be the explanation for the observed significant increase in total body water and derived values of fat free mass measured in our study. A similar increase in fat free mass was detected by decreasing skinfold measurements, however, which might be considered an unlikely response to substantial production of oedema fluid. Therefore the increment in fat free mass indicated both by isotope dilution and impedance was probably genuine and not affected by oedema. Despite significant decreases in skinfold thicknesses, the mean decrease in fat mass was not significant and as net changes in weight were positive, it appears that the most sensitive measure of changes in body composition resulting from hGH treatment is that of an increase in fat free mass. This change in fat free mass can be easily monitored in the clinical situation by either skinfold thickness measurements taken by a single observer, or, if this is clinically inconvenient and different observers have to be involved, by the technique of bioelectrical impedence, which has a lower interobserver coefficient of variation. ${ }^{18}$

Unlike those of previous studies in children,,$^{39}$ our results show a significant increase in both whole body resting energy expenditure and resting energy expenditure/kg fat free mass and also in whole body total energy expenditure. The percentage change is diminished when expressed as $\mathrm{kJ} / \mathrm{kg}$ fat free mass reflecting the concurrent increase in absolute fat free mass. This increase in resting energy expenditure may be related to an increase in metabolic activity of lean tissue due to increased protein turnover. However, the increase in resting energy expenditure is significantly associated only with changes in fat mass and not fat free mass, perhaps suggesting that the stored fat is the energy source for subsequent metabolic activity of fat free mass. The increase in resting energy expenditure is not as great as that seen in a recently published study on adults, ${ }^{30}$ probably reflecting the fact that some of our subjects were not as severely deficient in growth hormone and that measurements in the adult study were made after only four weeks of treatment. If the greatest metabolic effect of treatment (for example, nitrogen retention) occurs within two weeks of starting treatment and decreases thereafter, the measurable energy cost of such changes may be decreasing between four and six weeks.

If it is assumed that fat free mass contains $20.6 \%$ protein $^{31}$ and, as in children recovering from malnutrition and growing very rapidly, $1.4 \mathrm{~g}$ protein is synthesised/gram retained, ${ }^{32}$ then the minimum energy cost of the protein deposited in the increased fat free mass can be calculated from $3.75 \mathrm{~kJ} / \mathrm{g}$ protein deposited. This assumes four molecules ATP plus one molecule guanosine triphosphate are expended/ mole peptide bond synthesised. ${ }^{33}$ From these assumptions, the minimum energy cost of total protein synthesised for the mean increment of $1367 \mathrm{~g}$ in fat free mass (that is, net deposition of protein) measured over the initial six weeks of treatment (assuming an insignificant increase in fat free mass during the two week urine isotope collection before starting hGH) was $35 \mathrm{~kJ} /$ day. Thus only $7 \%$ of the observed mean increase in resting energy expenditure of $481 \mathrm{~kJ} /$ day can be accounted for by such mechanisms. As protein turnover (for which additional costs of protein breakdown, RNA turnover, and amino acid transport are small) and associated processes normally account for roughly $20 \%$ of resting energy expenditure, ${ }^{33}$ much of the observed increase in resting energy expenditure must be related either to non-protein metabolic effects of hGH treatment or to a much greater than normal increase in protein synthesis/g protein deposited. This remains to be studied.

This study is, as far as we are aware, the first 
in which simultaneous measurements of resting energy expenditure and total energy expenditure have been made in children. It is of interest that the ratio of total energy expenditure to resting energy expenditure is $1 \cdot 75: 1$, which is greater than the ratio of approximately $1 \cdot 5: 1$ for adults. ${ }^{34}$ This suggests that in children, a greater proportion of total energy expenditure is accounted for by activity than in adults. This and also the daily variability in behaviour likely to be exhibited by children is likely to be the explanation for the less significant increase in total energy expenditure than resting energy expenditure, though both increases were still correlated with each other and of a similar absolute magnitude. It appears that the increase in total energy expenditure is a reflection of the increase in the resting energy expenditure component of total energy expenditure and suggests that in children, $\mathrm{hGH}$ has no discernable effect on activity levels.

In conclusion, we have demonstrated that, in children undergoing hGH treatment, including those with normal variant short stature, clinically significant increases in fat free mass and body weight are detectable within six weeks of treatment. These changes are associated with increases in resting and total energy expenditure. Further studies are in progress to assess whether or not the extent of the observed changes are predictive of long term growth response to hGH treatment.

This work was supported by grants from the Biomedical Reseach Council of The Scottish Home and Health Department, NovoNordisk A/S, Birthright, The Wellcome Trust, The University of Dundee, and The European Social Fund. We are grateful to Dr S Ogston for statistical advice and to $\mathrm{Mr}$ M Rollo for assistance with some of the isotopic analysis.

1 Raben MS. Treatment of a pituitary dwarf with human growth hormone. $\mathcal{F}$ Clin Endocrinol Metab 1958;18:901-3.

2 Wright JC, Brasel JA, Aceto T, et al. Studies with huma growth hormone (HGH). An attempt to correlate metabolic response during short-term administration with linea growth during prolonged therapy. Am $\mathcal{f}$ Med 1965;38: $499-516$.

3 Prader A, Zachmann M, Poley JR, Illig R. The metabolic effect of a small uniform dose of human growth hormone in hypopituitary dwarfs and in control children. $A$ cto Endocrinol (Copenh) 1968;57:115-28.

4 Clayton BE, Tanner JM, Vince FP. Diagnostic and prognostic value of short-term metabolic response to human growth
hormone in short stature. Arch Dis Child 1971;46:405-13.

5 Rudman D, Kutner MH, Fleming GA, et al. Effect of 10-day courses of human growth hormone on height of short courses of human growth hormone on height of
children. F Clin Endocrinol Metab 1978;46:28-35.

6 children. F Clin Endocrinol Metab 1978;46:28-35. Urea synthesis, nitrogen balance, and glucose turnover in growth-hormone-deficient children before and after growth growth-hormone-deficient children before and after growt

7 Henneman DH, Henneman PH. Effects of human growth hormone on levels of blood and urinary carbohydrate and fat metabolites in man. $\mathcal{J}$ Clin Invest 1960;39:1239-45.

8 Collipp PJ, Curti V, Thomas J, Sharma RK, Maddaiah VT, Cohn SH. Body composition changes in children receiving human growth hormone. Metabolism 1973;22:589-95.

9 Brasel JA. Oxygen consumpton and growth. In: Cheek DB, ed. Human growth. Body composition, cell growth, energy and

10 Lifson N, Gordon GB, McClintock R. Measurement of tota carbon dioxide production by means of $\mathrm{D}_{2} \mathrm{O}^{18} . \mathcal{J} A \mathrm{pp}$ Physiol 1955;7:704-10.

11 Schoeller DA, van Santen E. Measurement of energy expenditure in humans by doubly labeled water method. f Appl Physiol 1982;53:955-9.

12 Hughes IA. Handbook of endocrine tests in children. Bristol: Wright, 1986:133-4.

13 Durnin JVGA, Rahaman MM. The assessment of the amount of fat in the human body from measurements of skinfold thickness. Br F Nutr 1967;21:681-9.

14 Brook CGD. Determination of body composition of children from skinfold measurements. Arch Dis Child 1971;46: $182-4$

15 Siri WE. Body composition from fluid spaces and density: analysis of methods. In: Brozek J, Henschel A, eds. Techniques for measuring body composition. Washington DC:

16 Schoeller DA, van Santen E, Peterson DW, et al. Total body water measurement in humans with ${ }^{18} \mathrm{O}$ and ${ }^{2} \mathrm{H}$ labeled water measurement in humans with 7 Clin Nutr 1980;33:2686-93.

17 Davies PSW, Preece MA, Hicks CJ, Halliday D. The prediction of total body water using bioelectrical impedance in tion of total body water using bioelectrical impedance in
children and adolescents. Ann Hum Biol 1988;15:237-40.

18 Gregory JW, Greene SA, Scrimgeour CM, Rennie MJ. Body water measurement in growth disorders: a comparison of bioelectrical impedance and skinfold thickness techniques with isotope dilution. Arch Dis Child 1991;66:220-2.

19 Pace N, Rathbun EN. Studies on body composition. The body water and chemically combined nitrogen content in relation to fat content. F Biol Chem 1945;158:685-91.

20 Klein PD, James WPT, Wong WW, et al. Calorimetric validation of the doubly-labelled water method for determination of energy expenditure in man. Hum Nutr:Clin Nutr 1984;38C:95-106.

21 Prentice AM, Coward WA, Davies HL, et al. Unexpectedly low levels of energy expenditure in healthy women. Lancet 1985;i:1419-22.

22 Roberts SB, Coward WA, Schlingenseipen K-H, Nohria V, Lucas A. Comparison of the doubly labeled water $\left({ }^{2} \mathrm{H}_{2}{ }^{18} \mathrm{O}\right)$ method with indirect calorimetry and a nutrient-balance method with indirect calorimetry and a nutrient-balance study for simultaneous determination of energy expenditure, water intake, and metabolizable energy intake
preterm infants. Am $\mathcal{f}$ Clin Nutr 1986;44:315-22.

preterm infants. Am $\mathcal{F}$ Clin Nutr 1986;44:315-22.
23 Schoeller DA, Levitsky LL, Bandini LG, Dietz WW, Walczak A. Energy expenditure and body composition in Prader-Willi syndrome. Metabolism 1988;37:115-20.

24 Black AE, Prentice AM, Coward WA. Use of food quotients to predict respiratory quotients for the doubly-labelled water method of measuring energy expenditure. Hum Nutr: Clin Nutr 1986;40C:381-91.

25 Weir JBdeV. New methods for calculating metabolic rate with special reference to protein metabolism. F Physiol 1949;109:1-9.

26 Scrimgeour CM, Rennie MJ. Automated measurement of the concentration and ${ }^{13} \mathrm{C}$ enrichment of carbon dioxide in breath and blood samples using the Finnigan MAT breath gas analysis system. Biomed Environ Mass Spectrom 1988; 15:365-7.

27 Wong WW, Lee LS, Klein PD. Deuterium and oxygen-18 measurements on microliter samples of urine, plasma, saliva, and human milk. Am $\mathcal{F}$ Clin Nutr 1987;45:905-13.

28 Coward WA, Prentice AM, Murgatroyd PR, et al. Measurement of $\mathrm{CO}_{2}$ and water production rates in man using ${ }^{2} \mathrm{H}$, ${ }^{18} \mathrm{O}$-labelled $\mathrm{H}_{2} \mathrm{O}$; comparisons between calorimeter and isotope values. In: van Es AJH, ed. Human energy metabolism: physical activity and energy expenditure measurements in epidemiological research based upon direct and indirect calorimetry. Euro-Nut, The Hague: Cip-Gegevans
Koninklijke Bibliotheck, 1985:126-8. (Series number 5.)

29 Crisp JA, Murgatroyd PR. A versatile and mobile microcomputerised system for indirect calorimetry. In: Human energy metabolism: physical activity and energy expenditure measurements in epidemiological research based upon direct and indirect calorimetry. Euro-Nut, The Hague: Cip-Gegevans Soninklijke Bibliotheck, 1985:44-45. (Series number 5.) treatment with recombinant human growth hormone on body composition and metabolism in adults with growth body composition and metabolism in adults with growth

31 Forbes GB. Human body composition. Growth, aging, nutrition, and activity. New York: Springer-Verlag, 1987:229.

32 Reeds PJ, Harris CI. Protein turnover in animals: man in his context. In: Waterlow JC, Stephen JML, eds. Nitrogen metabolism in man. London: Applied Science Publishers, 1981:391-408.

33 Waterlow JC, Millward DJ. Energy cost of turnover of protein and other cellular constituents. In: Wieser W, Gnaiger E, eds. Energy transformations in cells and organisms. Stuttgart: Georg Thieme Verlag, 1989:277-82.

34 Sims EAH, Danforth E. Expenditure and storage of energy in man. $\mathcal{F}$ Clin Invest 1987;79:1019-25.

35 Tanner JM, Whitehouse RH, Takaishi M. Standards from birth to maturity for height, weight, height velocity and weight velocity: British children, 1965. Part II. Arch Dis Child 1966;41:613-35. 